\title{
A paleointensity study on middle Miocene to Pliocene volcanic rocks from south-eastern Spain
}

\author{
M. Calvo-Rathert ${ }^{1}$, A. Goguitchaichvili² ${ }^{2}$ and N. Vegas-Tubía ${ }^{3}$ \\ ${ }^{1}$ Departamento de Física, EPS, Universidad de Burgos, c/ Francisco de Vitoria, s/n, 09006 Burgos, Spain \\ ${ }^{2}$ Laboratorio Interinstitucional de Magnetismo Natural, Instituto de Geofisica, Universidad Nacional Autonoma de Mexico, \\ Campus Morelia, Michoacan, Mexico \\ ${ }^{3}$ Departamento de Geodinámica, Universidad del País Vasco, 48080 Bilbao, Spain
}

(Received November 19, 2007; Revised April 17, 2008; Accepted May 5, 2008; Online published January 23, 2009)

\begin{abstract}
Thirteen middle-Miocene to Pliocene volcanic sites, belonging to four different types of volcanism (calcalkaline volcanism, potassic calc-alkaline and shoshonitic volcanism, lamproitic volcanism and basaltic alkaline volcanism), have been sampled in south-eastern Spain for paleointensity determinations. Rock-magnetic studies yield low-Ti titanomagnetite as the main carrier of remanence, showing also the presence of titanohematites in several cases. Analysis of hysteresis parameters indicates a PSD domain structure. Paleointensity determinations were performed with the Coe (1967) method. Of the 90 paleointensity determinations carried out, 29 provide successful determinations which fulfil selection criteria; most of these were in samples of lamproitic volcanism. Only four lamproitic sites out of the 13 studied ones yield reliable results. All have a similar age of approximately 7 M.y. Virtual dipole moments (VDM) of three of these display values between approximately $4 \cdot 10^{22} \mathrm{~A} \mathrm{~m}^{2}$ and $8 \cdot 10^{22} \mathrm{~A} \mathrm{~m}^{2}$, thus providing new paleointensity data for a time interval (between 4 and 8 M.a.), with a lack of Thellier-type paleointensity determinations. The fourth site shows a much lower paleointensity of $1.6 \cdot 10^{22} \mathrm{~A} \mathrm{~m}$, and may correspond to a polarity transition, in accordance with its paleo-directional results.
\end{abstract}

Key words: Paleointensity, rock magnetism, Neogene, volcanic rocks, Betic region.

\section{Introduction}

Absolute paleointensity determinations are important because of their geomagnetic value. A description of the whole magnetic field vector is of great importance for the study of the Earth's magnetic field and its changes with time, providing useful information to further our understanding of the working of the geodynamo and the conditions at the core-mantle boundary. Unfortunately, the amount of reliable paleointensity data available is still limited. A recent compilation of paleointensity results from the paleointensity database (Perrin and Schnepp, 2004) shows that available data are still scarce and unevenly distributed: over a thousand data per my for the first million years, 48 determinations per my in the 1-20 My interval, about 3 determinations per my for the 20-400 My interval, and much fewer than 0.04 determinations per my for older units.

Paleointensity determinations are much more difficult than estimations of the paleofield vector, and the failure rate of these experiments is often large. In addition, the dispersion observed in paleointensity results is much higher than those found in directional results, in many cases probably due to the fact that incorrect determinations are considered to reflect a correct paleointensity value. The paucity of available reliable paleointensity data is therefore intimately related to the difficulty of obtaining reliable absolute pale-

Copyright (c) The Society of Geomagnetism and Earth, Planetary and Space Sciences (SGEPSS); The Seismological Society of Japan; The Volcanological Society of Japan; The Geodetic Society of Japan; The Japanese Society for Planetary Sciences; TERRAPUB ointensity determinations.

Although several paleointensity determination methods have been proposed to date, those based on the original Thellier method (Thellier and Thellier, 1959; Coe, 1967) are the only ones relying on a stringent physical background; these can therefore be considered as the most reliable techniques to retrieve the absolute intensity of the geomagnetic field. However, in order to be suitable for paleointensity determinations, the studied samples must satisfy certain criteria: (1) the primary remanence of a rock must be a thermoremanence (TRM); (2) samples employed for paleointensity determinations must obey the Thellier laws of reciprocity, independence, and additivity of partial thermoremanent magnetization (pTRM) acquired in non-overlapping temperature intervals (Thellier and Thellier, 1959); (3) no significant irreversible chem$\mathrm{ical} /$ mineralogical or physical alterations that could affect magnetic phases should take place during heating.

Paleointensity results applying Thellier-type methods can be obtained from volcanic rocks and archeological material. The suitability of volcanic rocks with various chemical compositions has been discussed in numerous studies (see, for example, IAGA paleointensity database at the web site of the National geophysical Data Center (Geomagnetism) http://www.ngdc.noaa.gov/geomag/paleo.shtml). Nevertheless, it is rather difficult to find natural rocks that behave ideally in order to achieve reliable determinations. New paleointensity investigations can both provide new data as well as information about the suitability of the 


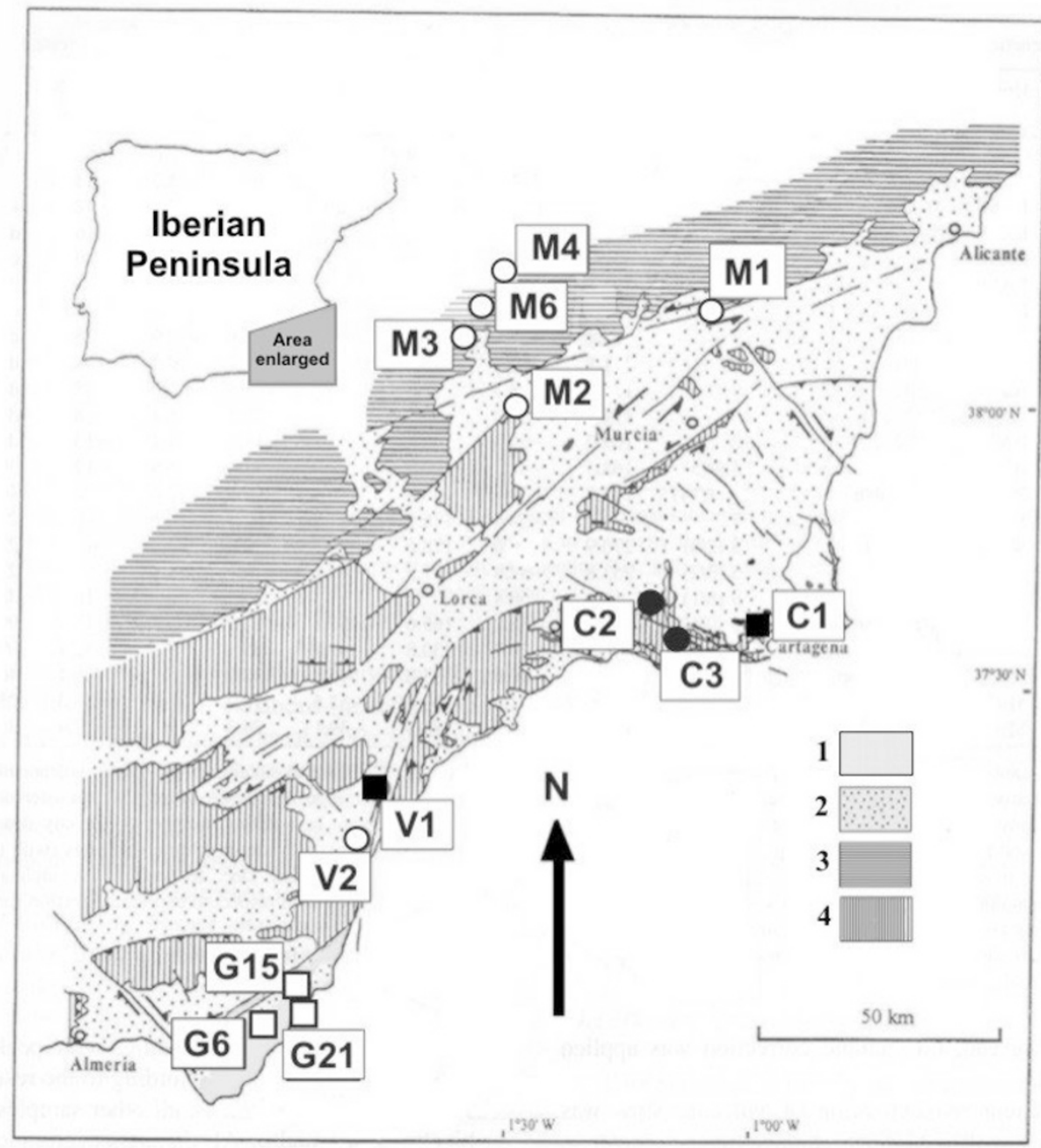

Fig. 1. Schematic geological map from south-eastern Spain and sampling sites (modified from Calvo et al., 1997). Black dots: Basaltic alkaline sites (C2 and C3). Black squares: Potassic calk-alkaline sites (C1 and V1). White dots: Lamproitic sites (M1, M2, M3, M4, M6 and V2). White squares: Calk-alkaline volcanism (sites G6, G15 and G21). 1: Calk-alkaline volcanism. 2: Neogene basins. 3: External Betics. 4: Internal Betics.

studied rocks for paleointensity determinations.

In order to add new paleointensity data to the already existing data set, we present here the results of our study of 13 volcanic sites of late Miocene and Pliocene age from south-eastern Spain. As the studied samples belong to four different types of volcanism, the results may also provide some information about their suitability for paleointensity determinations.

\section{Geological Setting and Sampling}

The Betic-Rif orogen is one of the major elements of the western Mediterranean Alpine chain. It developed during the late Mesozoic to Tertiary convergence between Africa and Iberia. Nevertheless, during the Miocene, the so-called Alborán domain and adjacent Internal Zones experienced considerable extension, while at the same time, shortening occurred in the External Zones of the Betic and Rif mountains (e.g., Platt and Vissers, 1989; García-Dueñas et al., 1992; Lonergan and White, 1997). This extension was accompanied and followed by igneous activity. The earliest manifestation of magmatism related to extension was the intrusion of a basaltic dyke-swarm with K-Ar ages of
22-23 m.y. (Torres-Roldán et al., 1986) and 30.2 \pm 0.9 m.y. (Turner et al., 1999) in the internal Betic zone north of Málaga.

Subsequently, widespread volcanic activity occurred in the Alborán region and in the south-eastern part of the Betic Mountains. This volcanism appears scattered around the region (Fig. 1), stretching more than $100 \mathrm{~km}$ northwards from the Mediterranean coast to the interior. It can also be followed southwards into the Alborán Sea. From a petrologic point of view, four types of volcanic rocks can be distinguished in the south-eastern Betic region: (1) calk-alkaline volcanics, (2) potassic calk-alkaline and shoshonitic volcanics, (3) lamproitic volcanics, and (4) basaltic-alkaline volcanics (Araña and Vegas, 1974; López Ruiz and Rodríguez Badiola, 1980; Bellon et al., 1983). Radiometric data obtained with both the K/Ar and ${ }^{40} \mathrm{Ar} /{ }^{39} \mathrm{Ar}$ radiometric dating methods are available for all four rock-types: calk-alkaline volcanic rocks provide ages between 6.9 and 12.2 m.y.; potassic calc-alkaline and shoshonitic volcanics, between 6.57 and 8.3 m.y.; lamproitic rocks, between 5.7 and 8.6 m.y.; basaltic-alkaline rocks, between 2.29 and 2.93 m.y. (Bellon et al., 1981a, b, 


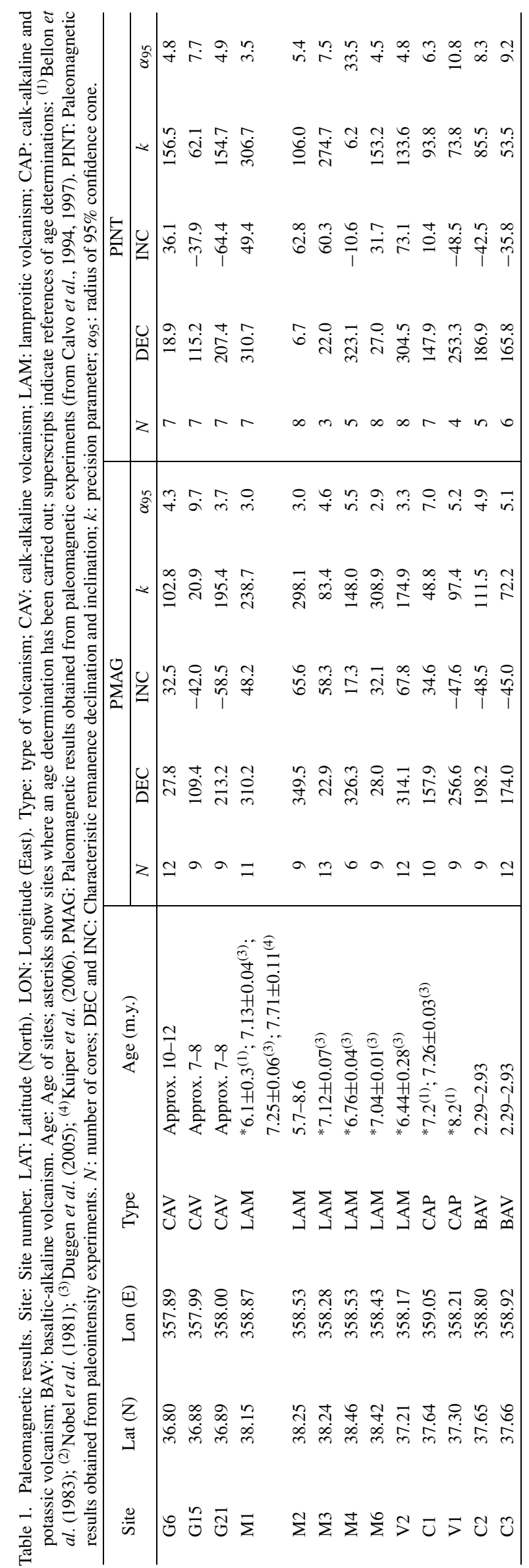

1983; Nobel et al., 1981; Di Battistini et al., 1987; Duggen et al., 2004, 2005; Kuiper et al., 2006). A detailed description of the petrology of south-east Iberian Neogene volcanism can be found, for example, in Duggen et al. (2005).

Only two paleomagnetic studies had been carried out previously on Neogene volcanics from south-eastern Spain, both with the goal of obtaining tectonic information in that region (Calvo et al., 1994, 1997). In those studies, paleomagnetic results from 33 volcanic sites belonging to all four previously mentioned types of volcanism and from 12 sedimentary sites were presented together with information from rock-magnetic experiments. Paleomagnetic and rockmagnetic results from both studies allowed a pre-selection of 13 volcanic sites which could be possibly suitable for paleointensity determinations, as all four types of volcanism were represented among them. For the present study, samples from all these sites have been sampled with a gasolinepowered portable drill and oriented by means of a magnetic compass. Three of the sampled sites belong to the calk-alkaline volcanics (G6, G15 and G21), six to the lamproitic volcanics (M1, M2, M3, M4, M6 and V2), two to the potassic calk-alkaline and shoshonitic volcanics $(\mathrm{C} 1$ and V1), and two to the basaltic-alkaline volcanics (C2 and C3). Sites in which a direct correlation with radiometric agedeterminations from other studies (Nobel et al., 1981; Bellon et al., 1983; Duggen et al., 2005; Kuiper et al., 2006) was possible, are indicated in Table 1. Location of all sampling sites is shown on Fig. 1.

\section{Rock-magnetic and Paleomagnetic Results}

The first pre-selection criterion used to choose suitable sites was based on demagnetization characteristics. Paleomagnetic results obtained in both previous paleomagnetic studies (Calvo et al., 1994, 1997) had shown that the 13 selected sites are characterized by a stable, mainly singlevector remanent magnetization in most of their samples, as shown by thermal and AF-demagnetization (Fig. 2). One of the sites (C2), however, also showed a second, presentday component, which nevertheless could clearly be separated from characteristic magnetization (ChRM). Depending on the sample, that secondary component was, however, either a negligible or a more important fraction of remanence. ChRM results obtained in both previous studies as well as NRM directions determined from paleointensity experiments are shown in Table 1. Departures of declination values from the expected N-S direction in the Cabo de Gata region and in sites $\mathrm{C} 1$ and $\mathrm{V} 1$ are probably due to block rotations in this region (Calvo et al., 1994, 1997), although secular variation may account for most of the between-site dispersion in many sites. Rock-magnetic experiments reported in both studies included induced magnetization versus temperature $\left(J_{\mathrm{S}}-T\right)$ curves, measurement of hysteresis parameters, measurement of isothermal remanent magnetization (IRM) acquisition curves, thermal demagnetization of two perpendicular IRM created in a strong $(0.9$ or $1.6 \mathrm{~T})$ and a weak $(0.1 \mathrm{~T})$ field, measurement of anisotropy of magnetic susceptibility (AMS), and ore microscopy (Table 2).

In addition, in the present study, new rock-magnetic experiments, consisting of measurements of susceptibility- 


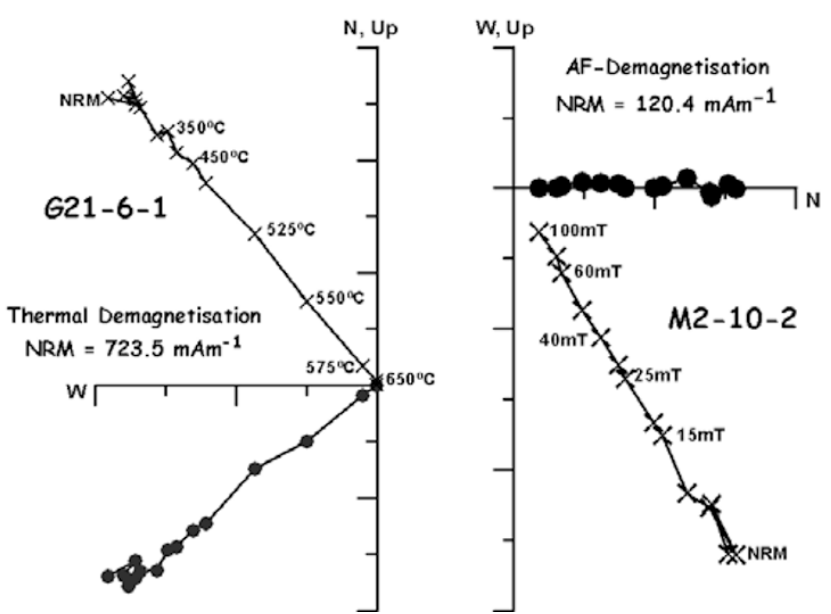

Fig. 2. Orthogonal vector demagnetization plots. Thermal demagnetization of sample G21-6-1 and AF-demagnetisation of sample M2-10-2. Dots are for the horizontal projection and crosses for the vertical projection.

versus temperature $(\kappa-T)$ curves and hysteresis parameters, have been performed. $\kappa-T$ curves were measured with a KLY-2 Kappabrigde in the paleomagnetic laboratory of the Universidad del País Vasco in Bilbao (Spain). Measurements were performed on whole-rock powdered samples, which were heated up to temperatures of around $700^{\circ} \mathrm{C}$ and cooled down to room-temperature in an argon atmosphere. Curie points were determined taking into account the inflexion points in $\kappa-T$ curves following the drop of susceptibility corresponding to the destruction of ferromagnetic phases. Although information on hysteresis parameters was already available from both of the above mentioned previous studies, new, more precise measurements were performed in the present study, as the magnetic signal of many of the samples had been shown to be very weak. Hysteresis parameters were measured at room temperature with a Micromag 2900 alternating gradient magnetometer in the paleomagnetic laboratory of the Universidad Nacional Autónoma of Mexico. With this device, a maximum field of $1.4 \mathrm{~T}$ can be applied. In Table 2, data from the new measurements are reported, except in those cases in which only the older data are available (C2 and M4).

Demagnetization characteristics and data obtained from rock magnetic studies point to low-Ti titanomagnetite as the main carrier of remanence in calk-alkaline volcanics (G6, G15 and G21) (Fig. 3). Ore microscopic observations in G15 show magnetite and exsolved ilmenite lamellae, an indicator of high-temperature oxidation. The presence of titanohematite, produced by hydrothermal alteration, is also detected in this sample. Hydrothermal alteration in that area was simultaneous with the emission of rocks (FernándezSoler, 1992), and thus not related to secondary components. Behavior during demagnetization of NRM and IRM suggests that remanence in potassic calk-alkaline samples (sites $\mathrm{C} 1$ and V1) could be carried by low-Ti titanomagnetite, although in the latter case a high-coercivity mineral with low-unblocking temperatures-probably titanohematitealso seems to be present, which is in agreement with low NRM and IRM intensities observed in V1. $J_{\mathrm{S}}-T$ curves

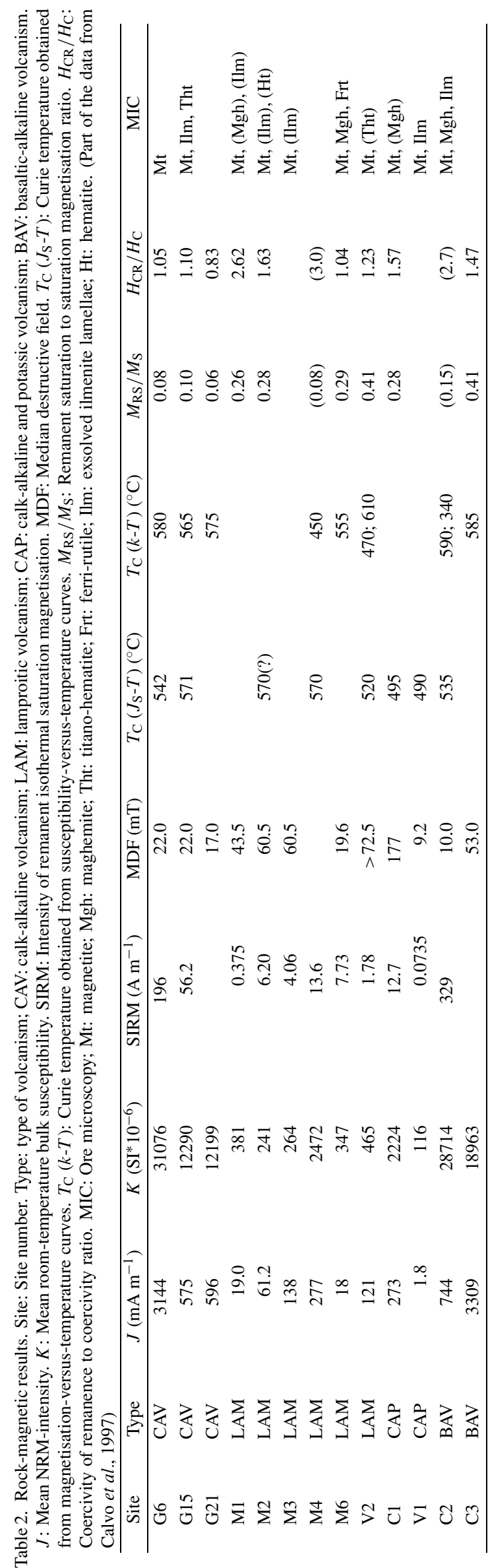



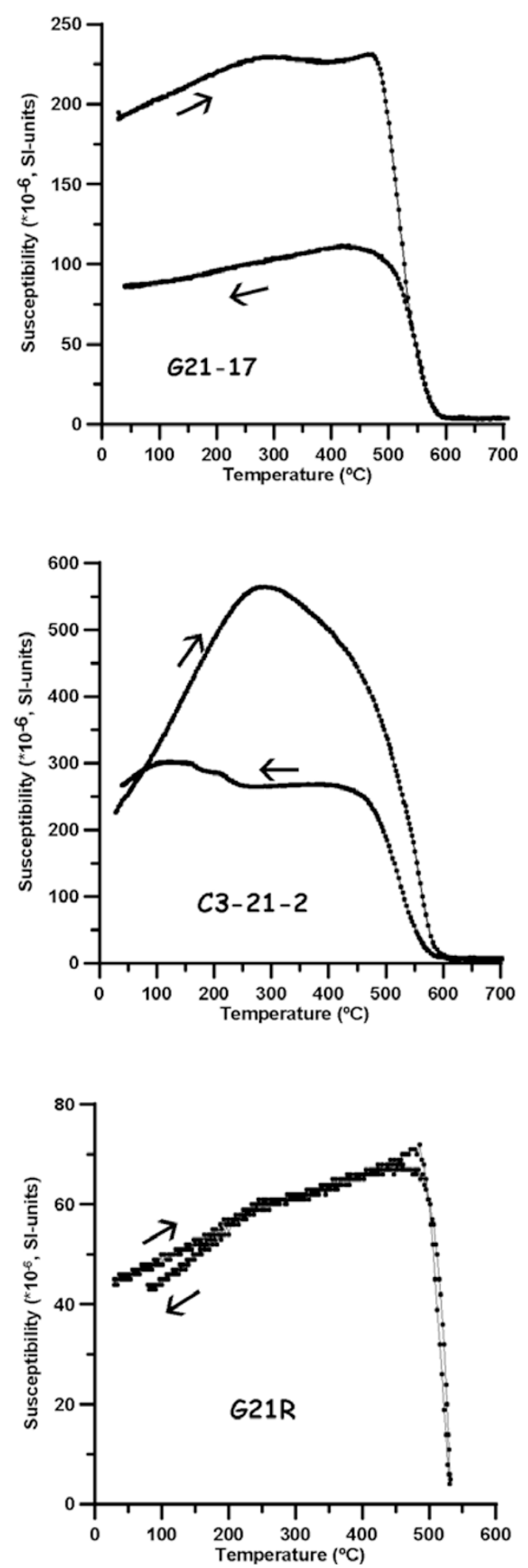

Fig. 3. Susceptibility versus temperature curves of samples G21-17, C3-21-2 and G21R. Arrows indicate the heating and cooling curves.

are difficult to interpret as the decrease of magnetization with temperature is gradual, thereby hindering unambiguous Curie-temperature determinations. Observed Curietemperatures are somewhat lower than expected for magnetite (Table 2). Also, lamproitic samples (sites M1, M2, M3, M4, M6, and V2) contain low-Ti titanomagnetite as a main carrier of remanence, but in all cases except M4, unblocking temperature spectra of NRM and IRM demagneti-

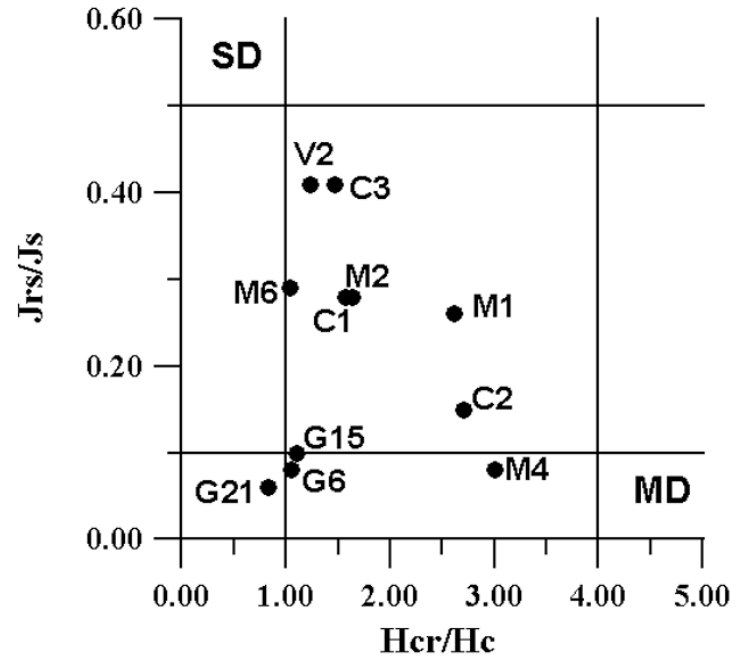

Fig. 4. Saturation remanence to saturation magnetization ratios as a function of coercivity of remanence to coercivity ratios (after Day et al., 1977). Site to which each studied specimen belongs is shown.

zation show the presence of high coercivity phases, probably also titanohematites, as shown by ore-microscopic studies. In these rocks, the weakness of the magnetic signal often obscured the characteristics of thermomagnetic curves and in some cases even prevented Curie-temperature determination. These difficulties may also account for the observed differences of Curie point values between the $J_{\mathrm{S}}-T$ and $k-T$ curves (Table 2). Basaltic alkaline samples (sites $\mathrm{C} 2$ and $\mathrm{C} 3$ ) contain magnetite as the main remanence carrier, and several specimens of site C2 also carry another low Curie-temperature phase, in agreement with Curietemperature determinations from $k-T$ curves. Ore microscopic studies of $\mathrm{C} 2$ show the presence of magnetite and exsolved ilmenite lamellae, thus indicating the occurrence of high-temperature oxidation.

$k-T$ curves were measured for most sites on one representative sample, except in site $\mathrm{C} 2$, where two samples were studied. Most curves showed an irreversible behavior (Fig. 3), with the exception of site M6, although the weak magnetic signal in this site provided a rather noisy $k-T$ curve. Although often the phase observed in the heating and cooling curves did not differ, susceptibility values did, showing lower values after heating up to $700^{\circ} \mathrm{C}$. A few specimens were measured performing some heatingcooling runs with progressively higher peak-temperatures in order to determine at which temperature significant alteration due to heating started. This experiment showed that in several cases irreversible changes started only at temperatures above $500^{\circ} \mathrm{C}$, although in $\mathrm{G} 15$, alterations could be already recognized at $300^{\circ} \mathrm{C}$.

Our analysis of hysteresis parameters shows a great scatter of values in the Day-plot (Day et al., 1977), with most points plotting in the pseudo-single domain (PSD) area (Fig. 4). Samples from M4 and C2 display multi-domainbehavior, although data from both sites could not be measured for the present study and come from the more unreliable older data set. Calk-alkaline volcanics show a more unusual combination of both low $J_{\mathrm{R}} / J_{\mathrm{S}}$ and $B_{\mathrm{CR}} / B_{\mathrm{C}}$ ratios. 
Table 3. Paleointensity results. Site: Site number; data from site M4 are shown with an asterisk (see text). Type: type of volcanism; CAV: calk-alkaline volcanism; LAM: lamproitic volcanism; CAP: calk-alkaline and potassic volcanism; BAV: basaltic-alkaline volcanism. $N$ : number of NRM-pTRM points used for paleointensity determination. Range: Temperature interval used for paleointensity determination. $f, g$ and $q$ : fraction of extrapolated NRM used, gap factor, and quality factor (Coe et al., 1978) respectively. $F \pm \sigma(F)$ : Paleointensity estimate for a single specimen and its standard error. Uncertainty in site M3 (1 single determination) has been calculated from the uncertainty of the paleointensity determination. VDM: Virtual dipole moment for a single specimen. Last three columns give average VDM values with site number (Site), number of paleointensity determinations (n) and average virtual dipole moment (VDMa).

\begin{tabular}{|c|c|c|c|c|c|c|c|c|c|c|c|}
\hline Specimen & Type & $n$ & Range & $F(\mu \mathrm{T})$ & $f$ & $g$ & $q$ & $M\left(\times 10^{22} \mathrm{~A} \mathrm{~m}^{2}\right)$ & Site & $N$ & Mean $M$ \\
\hline G6-14-2 & CAV & 10 & $113-505$ & $28.7 \pm 1.3$ & 0.72 & 0.71 & 10.9 & 6.81 & & & \\
\hline G6-17-1 & CAV & 12 & $113-540$ & $37.3 \pm 2.3$ & 0.97 & 0.81 & 12.9 & 8.32 & G6 & 2 & $7.6 \pm 1.1$ \\
\hline M1-2-1 & LAM & 9 & $113-410$ & $35.2 \pm 2.6$ & 0.67 & 0.86 & 7.8 & 7.49 & & & \\
\hline M1-3-2 & LAM & 10 & $113-428$ & $28.7 \pm 2.0$ & 0.79 & 0.88 & 9.9 & 5.62 & & & \\
\hline M1-4-3 & LAM & 6 & $113-357$ & $25.8 \pm 1.8$ & 0.48 & 0.79 & 5.4 & 4.57 & & & \\
\hline M1-5-2 & LAM & 10 & $113-428$ & $49.4 \pm 2.9$ & 0.60 & 0.88 & 8.9 & 9.93 & & & \\
\hline M1-8-1 & LAM & 9 & $113-428$ & $41.2 \pm 3.9$ & 0.53 & 0.86 & 4.8 & 7.78 & & & \\
\hline M1-10-4 & LAM & 10 & $113-428$ & $44.8 \pm 3.7$ & 0.53 & 0.87 & 5.6 & 8.72 & M1 & 6 & $7.4 \pm 1.3$ \\
\hline M2-6-3 & LAM & 11 & $113-440$ & $29.0 \pm 1.6$ & 0.62 & 0.88 & 10.1 & 4.82 & & & \\
\hline M2-9-1 & LAM & 11 & $113-440$ & $26.0 \pm 3.6$ & 0.93 & 0.79 & 5.4 & 4.41 & & & \\
\hline M2-12-2 & LAM & 9 & $165-428$ & $39.2 \pm 2.1$ & 0.47 & 0.87 & 7.5 & 7.17 & & & \\
\hline M2-14-2 & LAM & 9 & $113-428$ & $45.2 \pm 2.1$ & 0.81 & 0.85 & 14.5 & 7.87 & & & \\
\hline M2-15-3 & LAM & 13 & $113-477$ & $17.4 \pm 0.7$ & 0.85 & 0.89 & 18.6 & 2.94 & & & \\
\hline M2-17-3 & LAM & 11 & $113-451$ & $31.9 \pm 1.0$ & 0.80 & 0.87 & 21.5 & 5.11 & M2 & 6 & $5.4 \pm 2.0$ \\
\hline M3-5-2 & LAM & 11 & $208-477$ & $47.3 \pm 2.5$ & 0.71 & 0.58 & 7.9 & 7.95 & M3 & 1 & $8.0( \pm 0.4)$ \\
\hline M4-3-2* & LAM & 12 & $208-541$ & $9.0 \pm 0.8$ & 0.64 & 0.87 & 6.7 & 2.22 & & & \\
\hline M4-7-1* & LAM & 8 & $250-440$ & $6.2 \pm 0.5$ & 0.50 & 0.83 & 5.4 & 1.31 & & & \\
\hline M4-10-1* & LAM & 8 & $250-440$ & $5.6 \pm 0.4$ & 0.50 & 0.83 & 5.3 & 1.34 & & & \\
\hline M4-11-2* & LAM & 6 & $284-428$ & $6.2 \pm 0.2$ & 0.42 & 0.75 & 14.0 & 1.52 & M4 & 4 & $1.6 \pm 0.4$ \\
\hline M6-10-2 & LAM & 14 & $113-540$ & $18.4 \pm 1.0$ & 0.78 & 0.90 & 12.5 & 4.32 & & & \\
\hline M6-11-2 & LAM & 12 & $113-505$ & $20.5 \pm 1.5$ & 0.67 & 0.85 & 7.8 & 4.59 & & & \\
\hline M6-12-3 & LAM & 8 & $113-387$ & $12.7 \pm 0.6$ & 0.27 & 0.85 & 5.2 & 2.97 & & & \\
\hline M6-13-2 & LAM & 14 & $113-505$ & $14.8 \pm 0.5$ & 0.63 & 0.90 & 15.7 & 3.48 & & & \\
\hline M6-14-2 & LAM & 11 & $113-540$ & $17.9 \pm 1.0$ & 0.67 & 0.80 & 9.9 & 4.32 & & & \\
\hline M6-15-2 & LAM & 16 & $113-590$ & $15.0 \pm 0.3$ & 0.91 & 0.89 & 39.3 & 3.53 & & & \\
\hline M6-16-3 & LAM & 14 & $113-540$ & $12.8 \pm 0.4$ & 0.71 & 0.91 & 21.8 & 3.01 & & & \\
\hline M6-17-2 & LAM & 7 & $165-387$ & $15.9 \pm 0.6$ & 0.28 & 0.83 & 6.1 & 3.56 & M6 & 8 & $3.7 \pm 0.6$ \\
\hline C2-1-1 & BAV & 13 & $113-505$ & $48.2 \pm 3.4$ & 0.58 & 0.87 & 7.3 & 7.71 & & & \\
\hline C2-3-2 & BAV & 15 & $113-541$ & $31.4 \pm 1.3$ & 0.73 & 0.90 & 15.7 & 7.44 & $\mathrm{C} 2$ & 2 & $7.6 \pm 0.2$ \\
\hline
\end{tabular}

These latter data probably reflect the fact that remanence is not being carried only by magnetite.

\section{Paleointensity Experiments}

All paleointensity determinations were carried out using the Coe (1967) modification of the Thellier and Thellier (1959) stepwise double heating method, with a laboratory field set at $40 \mu \mathrm{T}$. This field could be held with a precision of $0.1 \mu \mathrm{T}$. Experiments were performed in the paleomagnetic laboratory of the University of Burgos using a TD48-SC furnace with controlled atmosphere chamber, with all heating-cooling runs being performed in an argon atmosphere. Temperature values were checked by means of a thermocouple placed inside the controlled atmosphere chamber, and temperature reproducibility between two heating runs to the same nominal temperature was within $3^{\circ} \mathrm{C}$. Samples were subjected to 16 double heatingcooling runs up to $590^{\circ} \mathrm{C}$ and, in addition, six pTRMchecks were performed after having heated the samples to $249,321,387,428,477^{\circ} \mathrm{C}$, and $540^{\circ} \mathrm{C}$. Paleointensity determinations were carried out on 90 standard-volume specimens belonging to 13 sites, all four types of volcanic rocks sampled in the studied region being represented.
Remanence was measured with a $2 \mathrm{G}$ cryogenic magnetometer. During the experiments, room-temperature bulksusceptibility was measured after the first of two heatingcooling runs at each temperature in order to check possible alterations of the magnetic mineralogy due to heating.

A set of criteria was chosen to determine whether paleointensity measurements could be considered successful. In order to be regarded as acceptable, paleointensity determinations had to satisfy all of the following requirements:

(1) Determinations had to be obtained from at least five aligned points on the NRM-pTRM diagram, without considering data suspected to correspond to the VRM acquired in situ. The initial NRM value was not included in paleointensity determinations.

(2) NRM fraction factor $f$ (Coe et al., 1978) should be larger than about $1 / 3$ with a quality factor of about 5 or larger (a $q$-value of 4.8 was accepted in one case).

(3) PTRM-checks should be positive in the interval chosen for intensity determination. PTRM-checks were considered to be positive if the repeat pTRM value agreed with the first measurement within $10 \%$.

(4) Directions of NRM end-points at each step obtained 
(a)
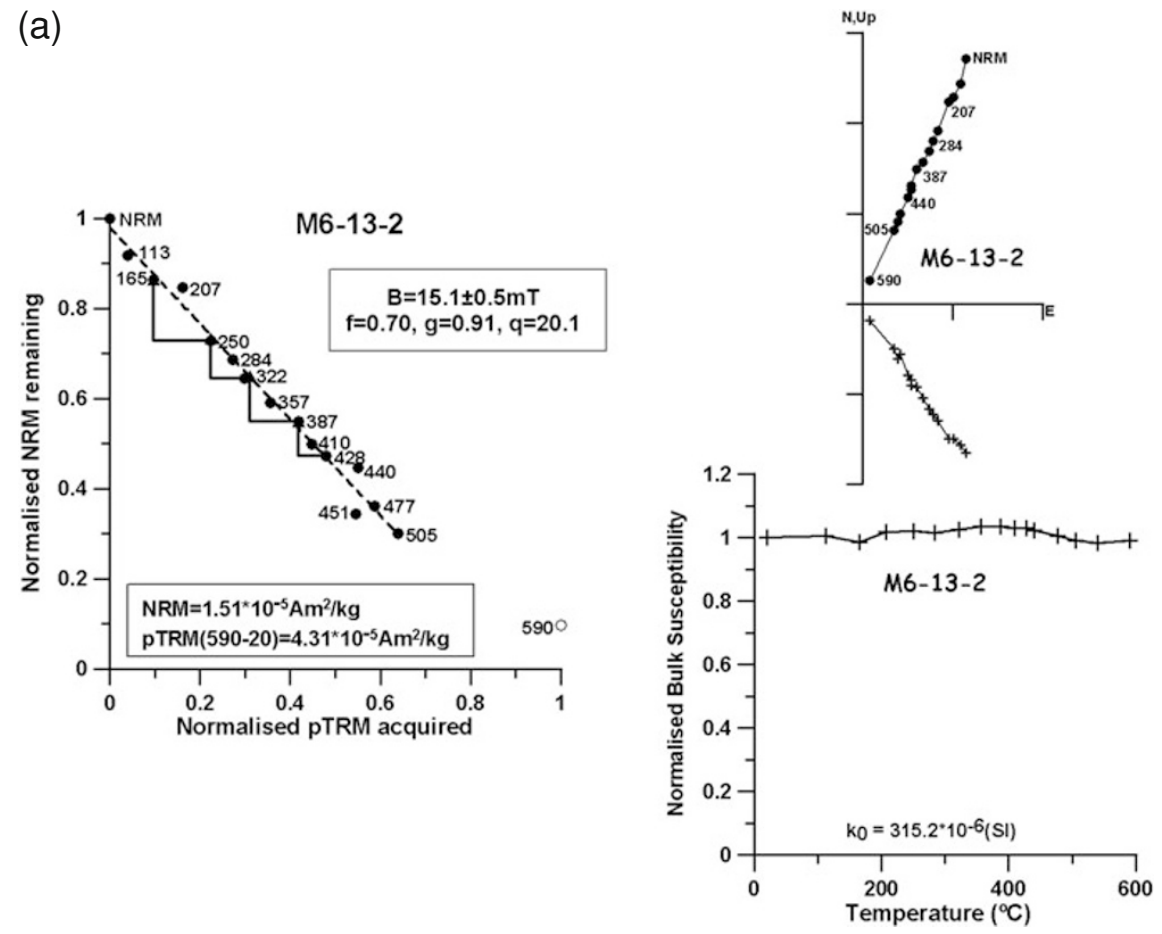

(b)
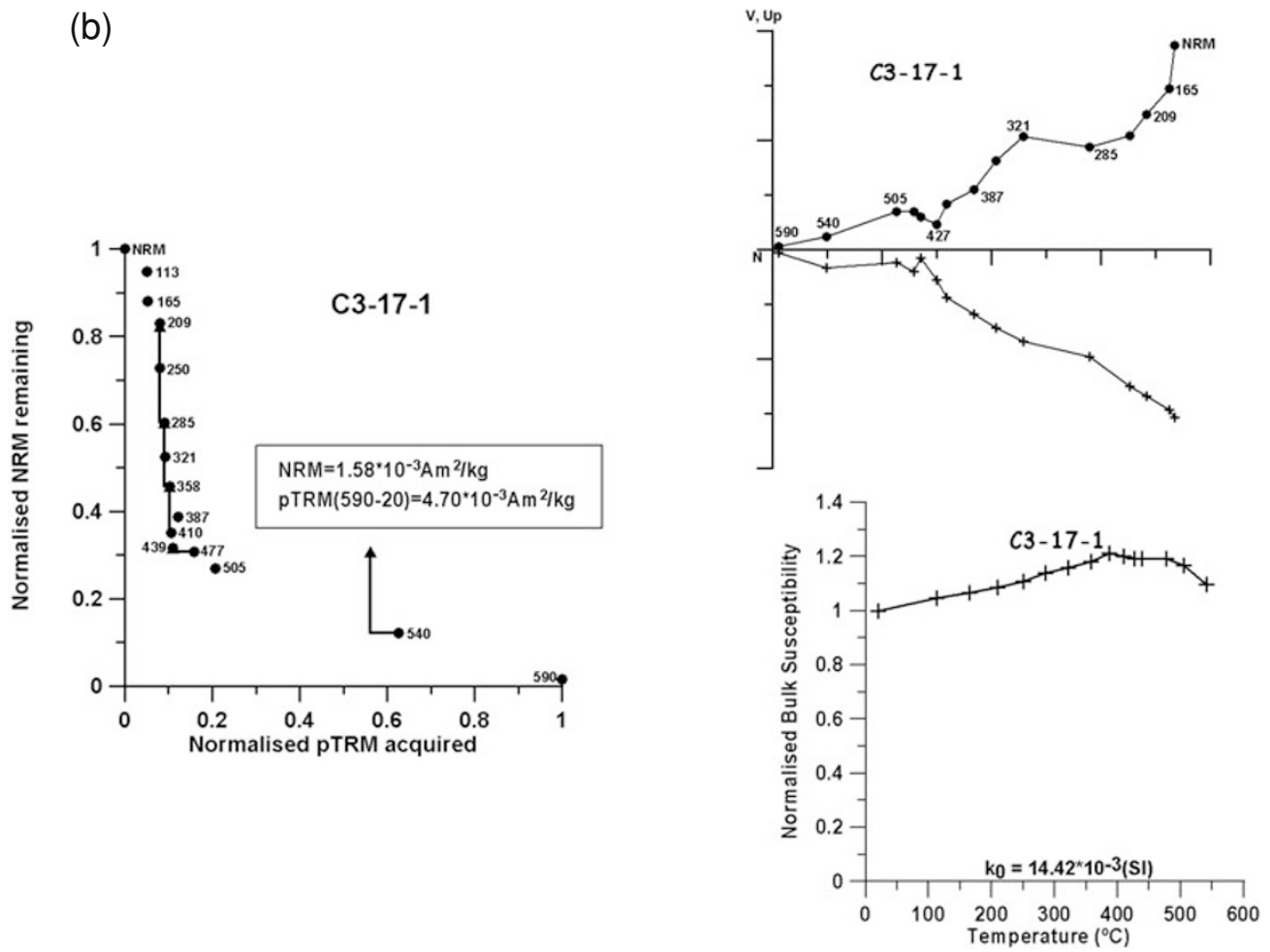

Fig. 5. Representative NRM-TRM plots, associated orthogonal vector demagnetization plots, and diagrams showing room-temperature bulk susceptibility after each heating step. In demagnetization plots, dots are for the horizontal projection and crosses for the vertical projection. (a): Successful determination of specimen M6-13-2; (b): Unsuccessful paleointensity experiment on specimen C3-17-1.

from paleointensity experiments should draw a straight line pointing to the origin in the interval chosen for paleointensity determination. No significant deviation in NRM directions towards the applied field direction should be observed.

(5) Paleointensity results obtained from NRM-pTRM diagrams should not show a clearly concave up shape. In such cases, determinations were not taken into ac- count, even if they fulfilled criteria (1) to (4), as in those cases remanence is probably related to the presence of multidomain (MD) grains (Levi et al., 1977).

\section{Results and Discussion}

When the aforementioned criteria are applied, 29 out of 90 paleointensity determinations provide acceptable results (Table 3), most of them in samples of lamproitic volcan- 
ism. Only two specimens belonging to calk-alkaline volcanism, both from site G6, a small lava flow, yield acceptable results. We obtain a similar result with basaltic alkaline volcanics, where only two specimens, both from lava flow $\mathrm{C} 2$, provide successful paleointensity determinations. None could be obtained from the potassic calk-alkaline group. Examples of paleointensity determinations are shown in Fig. 5. Unsuccessful paleointensity determinations in calkalkaline volcanics were often related to concave-up shaped Arai diagrams, reflecting a predominantly MD grain size in those samples, and also to alterations of magnetic mineralogy during heating. Potassic calk-alkaline and basaltic alkaline rocks usually proved to be thermally unstable during heating in paleointensity experiments.

Most samples from the lamproitic volcanic flow M4 seem to fulfil all acceptance criteria. Paleointensity results from this site yield low values, but since M4 is characterized by rather anomalous characteristic remanence directions (Table 2) and a low-latitude virtual geomagnetic pole $\left(\lambda=47.8^{\circ}\right)$, low paleointensities could be related to the occurrence of a polarity transition. In this site, however, NRM-directions obtained from demagnetization during paleointensity experiments differ significantly from NRMdirections directly determined in the same site in a previous paleomagnetic study (Calvo et al., 1997), with an angle of $28^{\circ}$ between both directions. This kind of behavior can only be observed in two sites, M4 and C1 (Table 2), the latter without any successful paleointensity determinations. In all other sites, the difference between directly determined NRM-directions and those obtained from paleointensity experiments is much smaller-in all cases lesser than the uncertainty given by the $\alpha_{95}$-values. As solar and magnetic compass readings carried out in the previous paleomagnetic studies performed on these rocks did not show significant differences in both sites M4 and C1, the anomalous behavior of both sites might be explained with an alteration caused by heating during the paleointensity experiment. Nevertheless, room-temperature susceptibility values only record slight increases after each new higher temperature step, and a $k-T$ experiment in which the sample was heated up to $310^{\circ} \mathrm{C}$ only shows slight differences between the heating and cooling curves. Despite the latter observations, some doubts remain about the reliability of paleointensity determinations from M4.

In addition to the very low paleointensities from site M4, with a mean of $6.8 \pm 1.5 \mu \mathrm{T}$, paleointensity results from site M6, a volcanic neck with lava flows, also show relatively low values $(16.0 \pm 2.8)$. Nevertheless, samples from this site provide the best paleointensity determinations of the present study and a reversible $k-T$ curve. All other sites display mean paleointensities mostly between 30 and $40 \mu \mathrm{T}$, although the result of site M3, also a volcanic neck, obtained from only a single specimen, yields a value near $50 \mu \mathrm{T}$. Sites M1, a volcanic body comprised of massive flows, and M2, a dike, both yield six successful determinations. With the exception of the latter, within-site scatter of intensity values is reasonably low in all cases. Intensities are lower than the $44 \mu \mathrm{T}$ expected for the present-day field, but most calculated virtual dipole moments (VDM) fit well into the wide range of values obtained in paleointensity

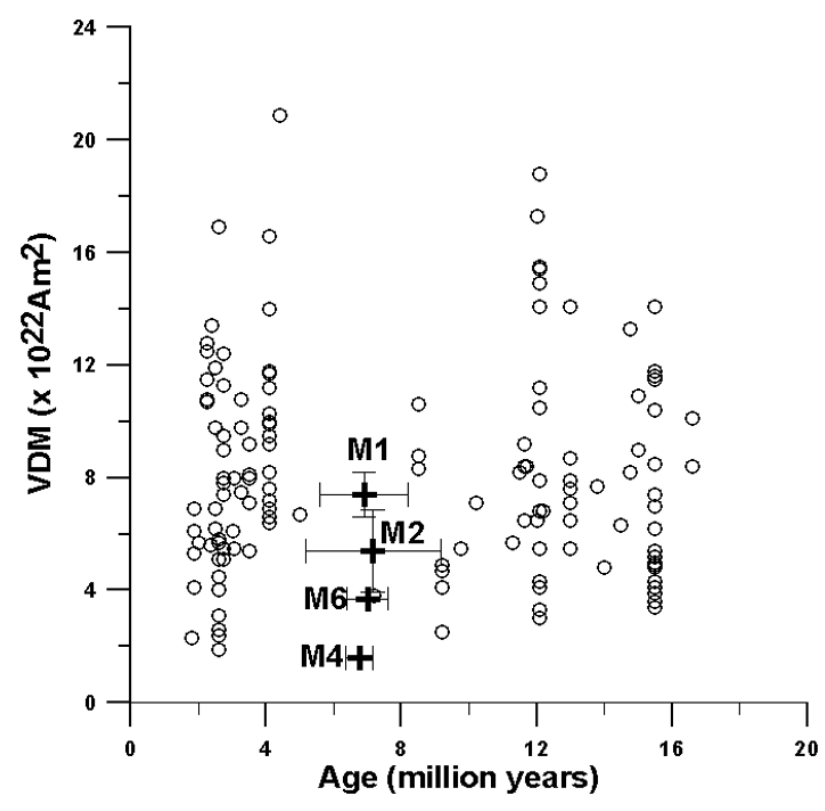

Fig. 6. Neogene VDM obtained from Thellier-type experiments or combined studies including Thellier type determinations. Data have been taken from the IAGA paleointensity database. Black dots show results from the present study.

studies on units from the same Middle-Miocene to Pliocene age (IAGA paleointensity database, Fig. 6).

It may be concluded that the Pliocene and Miocene volcanic rocks from the present study cannot be considered very suitable for paleointensity studies. Only three or four (if results from site M4 are considered reliable) out of 13 studied sites yielded reliable results, displaying only a moderate within-site scatter of intensity values. A few individual specimens also provided successful determinations, but six sites did not yield any acceptable paleointensity determination at all. Lamproitic volcanics seem to be the best suited for paleointensity determinations from the whole studied sample collection, but the three other kinds of volcanic rocks investigated are unable to provide almost any successful paleointensity determination. Due to the weakness of the magnetic signal which characterized lamproitic volcanics, rock-magnetic investigations were not able to provide clear clues for the reasons of a greater success-rate of paleointensity determinations on these rocks. However, the only fully reversible (though noisy) $k-T$ curve obtained in the present study when heating up to $700^{\circ} \mathrm{C}$ belonged to site M6, so that it might be conjectured that thermal stability during heating is the main reason for the successful paleointensity determinations on lamproitic volcanics. Unfortunately, in other thermomagnetic curves from lamproitic samples, the weak magnetic signal often obscured their characteristics, so that no clear conclusions could be obtained about the reversibility of these curves.

If sites with only one or two paleointensity results are not taken into account, four Messinian (upper Miocene) VDM are obtained in the present study. Three of these (sites M1, M2, and M6) display values between approximately $4 \cdot 10^{22} \mathrm{~A} \mathrm{~m}^{2}$ and $8 \cdot 10^{22} \mathrm{~A} \mathrm{~m}^{2}$, fitting well into the range of Neogene VDM values obtained by means of Thellier-type paleointensity determinations (IAGA paleoin- 
tensity database, Fig. 6). All three sites have a similar age of approximately 7 M.y. (Table 1), which coincides with a lack of Thellier-type determinations between 4 and 8 M.a. (Fig. 6). The fourth paleointensity value obtained in the present study shows a much lower paleointensity of $1.6 \cdot 10^{22} \mathrm{~A} \mathrm{~m}^{2}$, and if accepted as reliable, may correspond to a polarity transition, in accordance with its paleodirectional results.

Acknowledgments. We wish to thank M. Perrin and P. Roperch for their useful comments and suggestions on the manuscript. This research was supported by projects BU16/03 and BU028A06 (Junta de Castilla y León, Spain).

\section{References}

Araña, V. and R. Vegas, Plate tectonics and volcanism in the Gibraltar Arc, Tectonophysics, 24, 197-212, 1974.

Bellon, H., N. Q. Bau, V. Chaumont, and J. C. Phillipet, Implantation ionique de l'argon dans une cible support. Aplication au traçage isotopique de l'argon contenu dans les mineraux et les roches, C. R. Acad. Sci. Paris, 997-980, 1981a.

Bellon, H., G. Bizon, J. P. Calvo, E. Elizaga, J. Gaudant, and N. López Martínez, Le volcan du Cerro del Monagrillo (Province de Murcia): âge radiométrique et corrélations avec sédiments néogènes du bassin de Hellin (Espagne), C. R. Acad. Sci. Paris, 292, 1035-1038, 1981b.

Bellon, H., P. Bordet, and C. Montenat, Chronologie du magmatisme néogène des Cordillères Bétiques (Espagne meridionale), Bull. Soc. Geol. Fr., 25(2), 205-217, 1983.

Calvo, M., M. L. Osete, and R. Vegas, Palaeomagnetic rotations in opposite senses in southeastern Spain, Geophys. Res. Lett., 21(9), 761-764, 1994.

Calvo, M., R. Vegas, and M. L. Osete, Palaeomagnetic results from Upper Miocene and Pliocene rocks from the Internal Zone of the Iberian Peninsula, Tectonophysics, 277, 271-283, 1997.

Coe, R., Paleo-intensities of the earth's magnetic field determined from Tertiary and Quaternary rocks, J. Geophys. Res., 72, 3247-3262, 1967.

Coe, R., S. Grommé, and E. A. Mankinen, Geomagnetic paleointensities from radiocarbon-dated lava flows on Hawaii and the question of the Pacific nondipole low, J. Geophys. Res., 83, 1740-1756, 1978.

Day, R., M. Fuller, and V. A. Schmidt, Hysteresis properties of titanomagnetites: grain-size and compositional dependence, Phys. Earth Planet. Inter., 13, 260-267, 1977.

Di Battistini, G., L. Toscani, S. Iacarino, and I. M. Villa, K/Ar ages and the geological setting of calc-alkaline volcanic rocks from Sierra de Gata, S. E. Spain, Neues Jahrb. Miner. Monatsh., H8, 369-383, 1987.

Duggen, S., K. Hoernle, P. van den Bogaard, and C. Harris, Magmatic evolution of the Alboran Region: the role of subduction in forming the western Mediterranean and causing the Messinian Salinity Crisis, Earth Planet. Sci. Lett., 218, 91-108, 2004.

Duggen, S., K. Hoernle, P. van den Bogaard, and D. Garbe-Schönberg, Post-collisional transition from subduction to intraplate-type magmatism in the westernmost Mediterranean: Evidence for continental-edge delamination of subcontinental lithosphere, J. Petrol., 46, 1155-1201, doi:10.1093/petrology/egi013, 2005.

Fernández-Soler, J. M., El volcanismo calco-alcalino de Cabo de Gata (Almería). Estudio volcanológico y petrológico. $\mathrm{PhD}$ Thesis, Universidad de Granada, 243 pp., 1992.

García-Dueñas, V., J. C. Balanyá, and J. M. Martínez Martínez, Miocene extensional detachments in the outcropping basement of the northern Alboran basin (Betics) and their tectonic implications, GeoMar. Lett., 12, 88-95, 1992.

Kuiper, K. F., W. Krijgsman, M. Garcés, and J. R. Wijbrans, Revised isotopic (40Ar/39Ar) age for the lamproite volcano of Cabezos Negros, Fortuna Basin (Eastern Betics, SE Spain), Paleogeogr. Paleoclimatol. Paleoecol., 238, 53-63, 2006.

Levi, S., The effect of magnetite particle size on palaeointensity determinations of the geomagnetic field, Phys. Earth Planet. Inter., 13, 245-259, 1977.

Lonergan, L. and N. White, Origin of the Betic-Rif mountain belt, Tectonics, 16, 504-522, 1997.

López Ruiz, J. and E. Rodríguez Badiola, La región volcánica del sureste de España, Est. Geol., 36, 5-63, 1980.

Nobel, F. A., P. A. M. Andriessen, E. H. Hebera, H. N. A. Priem, and H. E. Rondeel, Isotopic dating of the post-alpine neogene volcanism in the Betic Cordilleras, Southern Spain, Geol. Mijnbouw, 60, 209-214, 1981.

Perrin, M. and E. Schnepp, IAGA paleointensity database: distribution and quality of the dataset, Phys. Earth Planet. Inter., 147(2-3), 255-267, 2004.

Platt, J. P. and R. L. M. Vissers, Extensional collapse of thickened continental litosphere: a working hypothese for the Alborán Sea and the Gibraltar arc, Geology, 17, 540-543, 1989.

Thellier, E. and O. Thellier, Sur l'intensité du champ magnetique terrestre dans le passé historique et geologique, Ann. Geophys., 15, 285-376, 1959.

Torres-Roldán, R. L., G. Poli, and A. Pecerillo, An early Miocene arctholeiitic magmatic dyke event from the Alboran Sea. Evidence for precollisional subduction and back-arc crustal extension in the westernmost Mediterranean, Geol. Rundschau, 75/1, 219-234, 1986.

Turner, S. P., J. P. Platt, R. M. M. George, S. P. Kelley, D. G. Pearson, and G. M. Novell, Magmatism associated with orogenic collapse of the Betic-Alboran Domain, SE Spain, J. Petrol., 40(6), 1011-1036, 1999.

M. Calvo-Rathert (e-mail: mcalvo@ubu.es), A. Goguitchaichvili, and N. Vegas-Tubía 